characteristics with frequent mucocutaneous involvement, alopecia, neuropsychiatric involvement, and lymphopenia. They should be followed carefully for early onset of LN.

Disclosure of Interest: None declared

DOI: 10.1136/annrheumdis-2017-eular.3964

\section{AB0526 B1 CD5+ LYMPHOCYTES IN SYSTEMIC LUPUS ERYTHEMATOSUS PATIENTS: RELATION TO DISEASE ACTIVITY}

S.I. Nasef ${ }^{1}$, H.H. Omar ${ }^{2}$, H.H. Omar ${ }^{3}$, M.S. Ghaly ${ }^{1} .{ }^{1}$ Physical Medicine, Rheumatology and Rehabilitation; ${ }^{2}$ Clinical Pathology; ${ }^{3}$ Internal Medicine, Faculty of Medicine, Suez Canal University, Ismailia, Egypt

Background: B cells are essential players in the pathogenesis of Systemic lupus erythematosus (SLE). Membrane CD5 elevates the threshold of B cell receptor mediated responses, and thus prevents the release of antibodies. So, misguided signalling through CD5 could lead to autoimmunity. Hence, CD5 ${ }^{+}$ $B$ cells were considered to play a paradoxical role in preventing rather than inducing autoimmunity. This challenging view differs from the old interpretation that elevated levels of B1 CD5+ cells in SLE patients represent a direct source of autoantibodies responsible for organ damage.

The clinical implications of this new concept for the role of $\mathrm{B} 1 \mathrm{CDF}^{+}$cells in SLE have not been fully addressed yet and there is no consensus agreement about the proportions of B1 CD5+ cells in SLE patients. Moreover, the relation of B1 $\mathrm{CD}^{+}$cells to disease activity and organ damage is not sufficiently studied.

Objectives: To assess the expression of $\mathrm{B}^{\mathrm{CD} 5^{+}}$cells in SLE patients and to evaluate their relationship with disease activity and organ damage.

Methods: We recruited 100 SLE patients and 100 healthy control subjects. Based on SLE disease activity index (SLEDAI), patients were divided into two groups: active SLE $(n=50)$ and inactive SLE $(n=50)$. SLE was active when SLEDAI was $>4$. The expression of $\left(\mathrm{CD}^{+} \mathrm{CD} 2 \mathrm{O}^{+}\right) \mathrm{B} 1$ cells was evaluated using flow cytometry. Lymphocytes were gated depending on both side and forward scatter. From the gated lymphocytes, B1a cells were identified double positive cells for CD20 and CD5. Percentage and absolute numbers of $\mathrm{CD}_{2} \mathrm{O}^{+} \mathrm{CD}^{+}$(B1a cells) and their mean fluorescence intensity (MFI) were measured. The histogram of CD5 expression was used to assess its expression on CD20 cells (figure 1).

Laboratory work included CBC, ESR, CRP, Serum creatinine, Protein/creatinine ratio, Urine analysis, 24 hour protein collection in urine, Complement levels, (Anti-dsDNA) and (ANA).

Results: Mean age of patients was $31.3 \pm 8.8$ years. Females constituted $94 \%$ $(n=94)$ of patients. Mean disease duration was $5.28 \pm 4.8$ years. Mean SLEDAI was $10.28 \pm 5.16$.

The proportions of $\left(\mathrm{CD}^{+} \mathrm{CD} 20^{+}\right) \mathrm{B} 1$ cells were significantly lower in SLE patients versus controls $(5.9 \pm 4.4 \%$ vs $20.2 \pm 4 \%, p \leq 0.001)$. Similarly, the absolute numbers of $\left(\mathrm{CDF}^{+} \mathrm{CD} 2 \mathrm{O}^{+}\right) \mathrm{B} 1$ cells $\left(\mathrm{cell} / \mathrm{mm}^{3}\right)$ were significantly lower in SLE patients versus controls $(100.2 \pm 103.4$ vs $557.6 \pm 163.3, p<0.001)$

The expression of $\left(\mathrm{CD}^{+} \mathrm{CD} 2 \mathrm{O}^{+}\right) \mathrm{B} 1$ cells was decreased in active SLE patients $(4.5 \pm 3.8 \%)$ in comparison to inactive patients $(7.3 \pm 4.7 \%)(p=0.027)$. B1 $\left(\mathrm{CDF}^{+} \mathrm{CD}^{2} \mathrm{O}^{+}\right)$absolute cell number $\left(\mathrm{cell} / \mathrm{mm}^{3}\right)$ was significantly lower in active SLE patients $(71.4 \pm 82.9)$ compared to inactive ones $(129.0 \pm 115.1)(P=0.047)$.
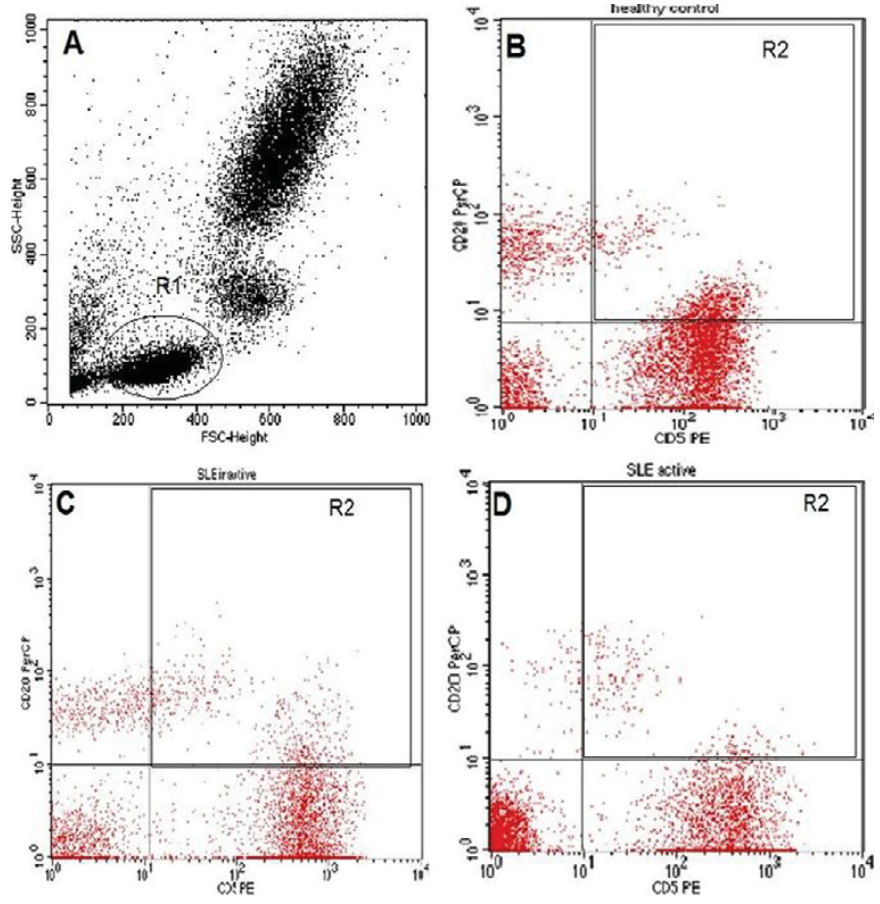

Figure 1
$\mathrm{MFI}$ of $\mathrm{CD}^{+} / \mathrm{CD}^{2} 0^{+}$was significantly decreased in SLE patients compared to healthy control $(146.9 \pm 109$ vs $196 \pm 48, P=0.033)$. B1 cells $\left(C D 5^{+} C D 20^{+}\right)$ correlated positively with $\mathrm{C} 3(\mathrm{r}=0.322, p=0.022)$ and $\mathrm{C} 4(\mathrm{r}=0.307, p=0.030)$. No correlation was found between $\left(\mathrm{CDF}^{+} \mathrm{CD} 2 \mathrm{O}^{+}\right) \mathrm{B} 1$ cells and disease duration, autoantibodies or any specific system or organ damage.

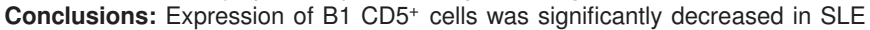
patients. Decreased $\mathrm{B} 1 \mathrm{CD}^{+}$cells expression was associated with higher disease activity. $\mathrm{B} 1 \mathrm{CD}^{+}$correlated positively with complement levels. These findings denote that CD5 expression on B cells may play a regulatory role in SLE pathogenesis and decrease occurrence of flares.

Disclosure of Interest: None declared

DOI: 10.1136/annrheumdis-2017-eular.2006

\section{AB0527 PROGRANULIN AND INSULIN-LIKE GROWTH FACTOR-2 AS BIOMARKERS FOR DISEASE ACTIVITY AND PATHOLOGICAL CHANGES IN LUPUS NEPHRITIS}

S. Goma, M. Abdelaziz, E. El-Hakeim, M. El Zohri, S. Sayed. Assiut University, Egypt, Assiut, Egypt

Background: Systemic lupus erythematosus (SLE) is a chronic autoimmune inflammatory disease (1), characterized by the production of autoantibodies, and formation of immune complexes due to the polyclonal activation of $T$ and $B$ lymphocytes that result in tissue and organ damage (2). During inflammation, neutrophils and macrophages release serine proteases to cleave progranulin (PGRN) into granulin (GRN), which exert their pro-inflammatory effects that counteract the anti-inflammatory effects of intact PGRN (3). Insulin-like growth factor-2 (ILGF-2) binds to insulin-like growth factors (IGFs) with high affinity (4). Although reports suggest that IGFBP-2 is a reliable biomarker of renal deterioration, it is still needed to confirm that it has high sensitivity and specificity in discriminating kidney disease caused by SLE from other origins.

Objectives: The aim of this study was to explore whether PGRN and ILGF-2 can be used as useful markers not only for accurate diagnosis of patients with active lupus nephritis (LN) but also for prediction of the disease activity in these patients. Methods: Twenty-five patients with systemic lupus erythematosus, twenty-five patients with chronic renal failure and twenty-five age- and sex-matched healthy volunteers were enrolled in the study. Routine laboratory investigations and measurement of serum PRGN and IGFBP-2 levels were done.

Results: Our results showed that the mean age of SLE, CRF and control groups $31.12 \pm 12.34,38.7 \pm 9.4$ and $32.96 \pm 13.66$ respectively with no significant difference between the three groups. There was female predominance in the three groups. Disease duration was $4.78 \pm 4.26$ in SLE patients. The mean of SLEDAI score was $15.04 \pm 7.54$. All renal biopsy results were class 2,3 , and 5 with a percentage of $32 \%, 24 \%$, and $44 \%$ respectively.

Table 1. Levels of PRGN and ILGF-2 in SLE, CRF and control groups

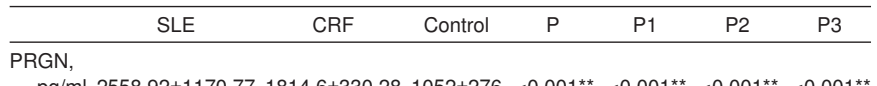

$\mathrm{pg} / \mathrm{m}$

IIGF-2,

$\mathrm{ng} / \mathrm{ml} \quad 26.44 \pm 11.55 \quad 6.14 \pm 2.25 \quad 3.3 \pm 1.7 \quad<0.001^{\star *}<0.001^{\star *}<0.001^{\star *} \quad 0.148$

P: Comparison between all groups. P1: comparison between SLE and CRF. P2: comparison between SLE and control. P3: comparison between CRF and control. Table 2. Levels of PRGN

and ILGF-2 in relation to SLEDAI score, renal SLEDAI, and Renal biopsy

\begin{tabular}{lcc}
\hline & PRGN $\mathrm{pg} / \mathrm{ml}$ & ILGF-2 $\mathrm{ng} / \mathrm{ml}$ \\
\hline SLEDAl score & & \\
$\quad$ Moderate & $1945.6 \pm 300$ & $26.8 \pm 11.7$ \\
High & $2072.1 \pm 545.5$ & $20.1 \pm 5$ \\
Very high & $4269.2 \pm 1106.8$ & $37.6 \pm 12.6$ \\
P value & $0.002^{\star \star}$ & $0.006^{\star *}$ \\
Renal SLEDAI & & \\
Inactive & $2251.2 \pm 841$ & $23.3 \pm 8.9$ \\
Active & $2764.1 \pm 1335$ & $28.6 \pm 12.9$ \\
P value & 0.311 & 0.196 \\
Renal biopsy & & \\
Class 2 & $2199.31 \pm 854.85$ & $24.38 \pm 13.31$ \\
Class 3 & $2244.17 \pm 767.97$ & $23.75 \pm 7.01$ \\
Class 4 & $2992.14 \pm 1453.93$ & $29.41 \pm 12.41$ \\
P value & 0.270 & 0.540 \\
\hline
\end{tabular}

SLEDAI: Systemic Lupus Erythematosus Disease Activity Index. *Statistically significant difference $(p<0.05){ }^{\star *}$ Statistically significant difference $(p<0.01)$

Conclusions: PGRN and ILGF-2 are significantly elevated in SLE than CRF and control and were associated with SLEDAI. Hence they are considered specific to LN.

References:

[1] Rahman A, Isenberg DA. (2008) Systemic lupus erythematosus. N Engl J Med 358:929-939.

[2] Kotzin BL. (1996) Systemic lupus erythematosus. Cell 85: 303-306.

[3] Park B, Buti L, Lee S et al. (2011) Granulin is a soluble cofactor for toll-like receptor 9 signaling. Immunity 34(4):505-513.

[4] Firth SM, Baxter RC. (2002) Cellular actions of the insulin-like growth factor binding proteins. Endocr Rev 23(6):824-54. 